\title{
Tubulointerstitial Nephritis Antigen-Like
}

National Cancer Institute

\section{Source}

National Cancer Institute. Tubulointerstitial Nephritis Antigen-Like. NCI Thesaurus. Code C158393.

Tubulointerstitial nephritis antigen-like ( $467 \mathrm{aa}, \sim 52 \mathrm{kDa}$ ) is encoded by the human

TINAGL1 gene. This protein may play a role in the modulation of receptor signaling. 